\title{
ASESMEN PERKEMBANGAN KOGNITIF ANAK USIA DINI (STUDI KASUS TK KHADIJAH AL-MUAYYADA SAMPANG)
}

\author{
Faizzatul Hasanah, Qurrotul Uyun \\ Institut Agama Islam Negeri Madura \\ Email: faizzatulhasanah11@gmail.com
}

\begin{abstract}
This research is a case study research with a qualitative descriptive approach conducted in Khadijah AlMuayyada Sampang. The purpose of this research is to know the material in developing children's cognitive activities, describing the application of assessment techniques, and the results/impact of cognitive development assesments in TK Khadijah Al-Muayyada Sampang. Data collection techniques that the author does is observation then proceed with the interview. The results of this study indicate that material in developing children's cognitive activities in the form of the concept of numbers, recognize, group, connect, and sort objects based on size, color, shape, function, and other characteristics. Assessment techniques used are observation, checklist, and masterpiece. Assessment has a positive impact on achieving cognitive development, both for teachers, students, and parents.
\end{abstract}

Keywords: Assessment, Cognitive, Early Childhood

\begin{abstract}
Abstrak
Penelitian ini merupakan penelitian studi kasus dengan pendekatan deskripstif kualitatif yang dilakukan di TK Khadijah Al-Muayyada Sampang. Tujuan dari penelitian ini adalah mengetahui materi kegiatan dalammengembangkan kognitif anak, mendeskripsikan penerapan teknik asesmen (penilaian), dan hasil/dampak adanya asesmen perkembangan kognitif di TK Khadijah Al-Muayyada Sampang. Teknik pengumpulan data yang penulis lakukan adalah observasi kemudian dilanjutkan dengan wawancara. Hasil penelitian ini menunjukkan bahwa materi kegiatan dalam mengembangkan kognitif anak berupa konsep bilangan, mengenal, mengelompokkan, menghubungkan dan mengurutkan benda berdasarkan ukuran, warna, bentuk, fungsi, dan ciri-ciri lainnya. Teknik penilaian yang digunakan yaitu observasi, checklist, dan hasil karya. Asesmen meiliki dampak positif dalam pencapaian perkembangan kognitif, baik untuk guru, anak didik, maupun orang tua.
\end{abstract}

Kata Kunci: Asesmen, Kognitif, Anak Usia Dini 


\section{PENDAHULUAN}

Pendidikan Anak Usia Dini (PAUD) sebagai layanan pendidikan pra-sekolah untuk anak usia dini memiliki peranan penting di dalam mengembangkan semua aspek perkembangan dan segala potensi anak. Berbagai bentuk stimulus yang diberikan pendidik bertujuan untuk mencapai STPPA (standar tingkat pencapaian perkembangan anak) yang disusun daalam berbagai bentuk bermain sambil belajar. Melalui berbagai kegiatan tersebut diharapkan anak mampu mencapai berbagai capaian perkembangan yang sudah ditetapkan sesuai dengan Permendikbud No. 137 Tahun 2014 tentang Standar Nasional Pendidikan Anak Usia Dini.

Sebagai pendidik atau calon pendidik yang menekuni bidang pendidikan anak usia dini, mengetahui perkembangan dan kemajuan belajar dan aspek perkembangan anak didik adalah mutlak dibutuhkan. Kita harus mengetahui sejauh mana perkembangan anak, karakteristik, hambatan apa yang dihadapi anak, laju perkembangannya, dan hal lain yang berhubungan dengan anak dapat kita ketahui melalui proses asesmen.

Asesmen berasal dari istilah bahasa Inggris, yaitu assesment, namun istilah assesment sudah ditetapkan menjadi istilah dalam bahasa Indonesia, yaitu asesmen. Asesmen yaitu suatu proses pengamatan, pencatatan, dan pendokumentasian kinerja dan karya siswa dan bagaiman ia melakukannya sebagai dasar pengambilan keputusan pendidikan anak yang berguna bagi siswa (Suyanto, 2005:195). Sejalan dengan itu, E Johnson sebagaimana dikutip Nugraha (2008: 8) memandang bahwa penilaian merupakan suatu proses memilih, mengumpulkan, dan menafsirkan informasi untuk membuat keputusan. Dalam Permendikbud No. 146 Tahun 2014 dijelaskan bahwa penilaian adalah proses pengumpulan dan pengolahan informasi untuk mengukur capaian kegiatan belajar anak. Ketiga pengertian tersebut menurut Fadlillah (2017: 208) mempunyai makna yang sama antara satu dan yang lain.artinya dalam penilaian dimaksudkan untuk menggaliberbagai informasi dari peserta didik guna untuk mengetahui perkembangannya.

Dalam kaitannya dengan pendidikan anak usia dini, penilaian sebagai prosedur sistematis yang digunakan untuk mendapatkan informasi tentang kinerja dan atau kemajuan berbagai aspek perkembangan yang dapat dicapai peserta didik seteah mengikuti kegiatan pembiasaan dalam kurun waktu tertentu. Penilaian merupakan proses pengumpulan dan pengolahan informasi untuk menentukan tingkat pencapaian perkembangan anak dan pengambilan keputusan, pengakuan, atau ketepatan tentang kondisi atau kemampuan anak (Wahyudin dan Agustin, 2011: 51).

Dapat disimpulkan bahwa penilaian atau asesmen dalam pendidikan anak usia dini dimaksudkan untuk mengetahui capaian perkembangan anak yang lebih ditekankan pada proses, bukan hasil akhir yang didapatkan. Sebagaimana diungkapkan Suyanto (2005: 195) bahwa asesmen atau penilaian tidak dilakukan di kelas akhir program atau di akhir tahun TK, tetapi dilakuakn secara bertahap dan berkesinambungan sehingga kemajuan belajar siswa dapat diketahui.

Menurut Direktorat Pendidikan Anak Usia Dini tujuan dari asesmen ialah untuk mengetahui dan menindaklanjuti pertumbuhan dan perkembangan yang yang dicapai peserta didik selama mengikuti pendidikan. Pertumbuhan dan perkembangan tersebut mencakup semua aspek perkembangan anak secara individual, yang meliputi aspek fisik motorik, kognitif, bahasa, sosial emosianal, nilai agama dan moral, dan seni.

Sejalan dengan hal diatas, menurut Suyadi (2016: 75) hasil asesmen perkembangan anak dapat digunakan untuk: (1) laporan perkembangan dari berbagai bidang pengembangan, yaitu kognitif, bahasa, fisik/motorik, sosial dan emosial, perilaku (pembiasaan moral dan sikap beragama, disiplin). Selain itu juga digunakan untuk mengetahui minat, kecakapan khusus; (2) sebagai laporan tertulis pada orangtua tentang perkembangan anak; serta (3) digunakan untuk memberikan laporan secara periodik tentang 
kemajuan lembaga pada pihak-pihak yang terkait. Untuk kegunaan kegiatan pembelajaran, hasil asesmen perkembangan anak dapat digunakan untuk kepentingan pembelajaran/kegiatan, yakni dalam hal: (1) memberikan data yang dapat digunakan untuk memperbaiki dan mengembangkan pembelajaran/kegiatan; (2) mengidentifikasi perkembangan anak selama mengikuti pembelajaran/kegiatan. Untuk kegunaan diagnostik, hasil asesmen perkembangan anak dapat digunakan sebagai alat diagnostik dalam bimbingan dan konseling dalam mengananalisis berbagai permasalahan anak. Untuk Kegunaan Penelitian, hasil asesmen perkembangan anak dapat digunakan untuk bahan penelitian terkait perkembangan. Penelitian ini dilakukan dalam upaya pengembangan potensi secara optimal.

Menurut Rosyid dalam Ernawita (2018: 3) dalam proses pembelajaran anak usia dini terdapat asesmen yang difokuskan pada tiga wilayah yaitu perkembangan bahasa, kognitiflogika, dan motorik. Dalam kaitannya penilaian yang difokuskan pada intelektual atau perkembanagan pemikiran pada anak usia dini merupakan ranah asesmen atau penilaian kognitif.

Kognitif adalah suatu proses berpikir, yaitu kemampuan individu untuk menghubungkan, menilai, dan mempertimbangkan suatu kejadian atau peristiwa. Proses kognitif berhubungan dengan tingkat kecerdasan (iintelegensi) yang menandai seseorang dengan berbagai minat terutama sekali ditujukan kepada ide-ide belajar (Syah, 2010: 64).

Menurut Masyitoh (2019: 30) Perkembangan kognitif pada hakekatnya merupakan proses mental untuk mengidentifikasi, mengingat, menghubungkan (korelasi dan asosiasi), membilang, menjelaskan, mengklasifikasi, menganalisis, mensintesis, serta mengaplikasikan sesuatu. Perkembangan kognitif dapat juga dimaknai sebagai kemampuan untuk memecahkan masalah atau menciptakan karya yang dihargai dalam suatu budaya.

Seorang pakar terkemuka dalam disiplin psikologi kognitif dan psikologi anak, Jean Piaget (sebut: Jean Piasye) dalam Syah (2010: 74), yang hidup antara tahun 1896 sampai tahun 1980, mengklasifikasikan perkembangan kognitif anak menjadi empat tahapan.

1. Tahap sensory-motor, yakni perkembangan ranah kognitif yang terjadi pada usia $0-2$ tahun. Anak pada periode ini belajar cara mengikuti dunia kebendaan secara praktis dan belajar menimbulkan efek tertentu tanpa memahami hal yang sedang ia perbuat kecuali hanya mencari cara melakukan perbuatan seperti diatas.

2. Tahap pra-operational, yakni perkembangan ranah kognitif yang terjadi pada usia 2-7 tahun. Pada periode ini anak mengembangkan deferred-imitation (peniruan yang tertunda) yakni kapasitas meniru perilaku orang lain yang sebelumnya pernah ia lihat untuk mereapons lingkungan. Muncul pula insight-learning, yakni gejala belajar berdasarkan tilikan akal. Dalam periode ini juga diperoleh kemampuan berbahasa dimana ank mulai mampu menggunakan kata-kata yang benar dan mampu pula mengekspresikan kalimat-kalimat pendek tapi efektif.

3. Tahap concrete-operational, yang terjadi pada usia 7-11 tahun. Pada periode ini nak memperoleh tambahan kemampuan yang disebut Isystem of operations (satuan langkah berpikir). Kemampuan satuan langkah berpikir ini berfaedah bagi anak untuk mengoodinasikan pemikiran dan idenya dengan peristiwa tertentu ke dalam sistem pemikirannya sendiri.

4. Tahap formal-operational, yakni perkembangan ranah kognitif yang terjadi pada usia 11-15 tahun. Anak memilki kemampuan mengoordinasikan baik secara serentak maupun berurutan 2 ragam kemampuan kognitif, yakni: 1) kapasitas menngunakan hipotesis; 2) kapasitas menggunakan prinsip-prinsip abstrak. (Daehler \& Bukatko, 1985; Best, 1989; Anderson, 1990).

Keempat tahapan perkembangan kognitif itu penting dicapai oleh anak melalui berbagai kegiatan bermain dan belajar di sekolah. Disinilah guru memiliki peranan dalam 
mengasesmen (menilai) perkembangan anak sebagai bahan tindak lanjut capaian perkembangan dan tujuan pembelajaran, dengan menggunakan teknik-teknik asesmen yang sudah ditentukan pihak sekolah. Untuk itu pada karya ilmiah ini penulis akan membahas tentang "Asesmen Perkembangan Kognitif Anak Usia Dini (Studi Kasus TK Khadijah Al-Muayyada Sampang)" yang terletak di Kota Sampang Madura Provinsi Jawa Timur. Tujuan dari penulisan karya ilmiah ini adalah untuk mengetahui materi kegiatan/stimulus yang digunakan dalam aspek perkembangan kognitif, mendeskripsikan penerapan teknik asesmen (penilaian), dan hasil/dampak adanya asesmen perkembangan kognitif di TK Khadijah Al-Muayyada Sampang.

\section{METODE PENELITIAN}

Metode yang digunakan dalam penelitian ini adalah penelitian deskriptif kualitatif, yaitu penelitian yang dilakukan melalui pendekatan kualitatif dan dideskripsikan dalam bentuk kata-kata tertulis atau lisan dari orang dan perilaku yang dapat diamati (Moleong, 2011: 4). Sehingga peneliti mengakaji data dari TK Khadijah Al-Muayyada Sampang yang kemudian mendeskripsikan data tersebut sesuai dengan realita. Subjek dalam penelitian adalah pihak-pihak yang terkait dan memiliki peran penting di TK Khadijah Al-Muayyada Sampang. Adapun sumber data dalam penelitian dibagi menjadi dua kategori, yaitu kategori manusia dan non manusia. Sumber data kategori manusia yaitu guru kelas TK Khadijah AlMuayyada Sampang. Sedangkan sumber data non manusia adalah hasil asesmen anak. Teknik pengumpulan data yang dilakukan peneliti, yakni wawancara semi-terstruktur yang dicatat dalam bentuk dokumentasi berupa asesmen perkembanga kognitif yang dilakukan TK Khadijah Al-Muayyada Sampang. Penelitian ini dilakukan di TK Khadijah AlMuayyada Desa Gunung Maddah Kecamatan Sampang yang dilaksanakan selama dua hari, yaitu hari jum'at dan sabtu. Mengenai pengecekan keabsahan hasil penelitian, peneliti menggunakan teknik wawancara dengan salah satu guru pengajar di TK Khadijah AlMuayyada Sampang.

\section{HASIL DAN PEMBAHASAN}

Pada dasarnya setiap anak di TK Khadijah Al-Muayyada Sampang memiliki potensi yang sama dengan kemampuan yang berbeda dan berhak untuk dikembangkan. Dalam hal ini khususnya perkembangan kognitif, karena pada dasarnya anak sangat ditentukan oleh kualitas otak, maka sudah kewajiban seorang pendidik dari lembaga tersebut untuk berupaya bagaimana anak didiknya mampu cerdas dalam segi intelegensi. Intelegensi adalah kemampuan mental, kemampuan kecerdasan serta kemampuan memecahkan masalah atau untuk menciptakan karya.

Untuk mengembangkan kognitif anak usia dini, TK Khadijah Al-Muayyada Sampang tersebut memberikan stimulus berupa materi kegiatan yang dikemas dengan prinsip bermain sambil belajar dengan metode yang menyenangkan dan memeberikan pengalaman secara langsung kepada anak, sehingga mereka mampu memecahkan masalah/persoalan yang ada dihadapan mereka. Materi kegiatan tersebut seperti: a). Mengajarkan anak tentang konsep matematika seperti mengenal angka 1-10 dan mampu menuliskannya; b) Mengenal dan mengelompokkan benda berdasarkan bentuk, ukuran, warna, fungsi, dan ciri-ciri lainnya; c) Menghubungkan/mencocokkan benda berdasarkan kesamaan bentuk, jumlah, dan ciri lainnya; d) Mengurutkan benda ukuran, bentuk, warna, dan ciri lainnya.

Dengan berbagai macam kegiatan dan metode yang diberikan, guru TK tersebut berharap anak-anak lebih giat dan semangat untuk belajar sehingga kognitif anak mampu berkembang dan bisa menjadi bekal untuk jenjang berikutnya, terlepas dari setiap anak memiliki perbedaan kecepatan perkembangan, ada yang cepat dan ada pula yang lambat. Sehingga yang terpenting menurut guru di TK tersebut adalah penyampaiannya harus 
bertahap dan menyenangkan, disesuaikan dengan kemampuan dan tahap perkembangan anak (Farhah: Wawancara).

Hal tersebut sesuai dengan pendapat Sujiono (2013: 2) bahwasannya proses pembelajaran pada anak usia dini hendaknya dilakukan dengan tujuan memberikan konsepkonsep dasar yang memiliki kebermaknaan bagi anak melalui pengalaman nyata yang memungkinkan anak untuk menunjukan aktivitas dan rasa ingin tahu (coriousity) secara optimal.

Untuk mengukur perkembangan kognitif AUD, terrdapat beberapa teknik dan cara dalam asesmen PAUD yaitu: 1. Observasi, yaitu asesmen yang dilakukan dengan cara mengamati secara langsung perilaku dan perkembangan anak secara terus menerus; 2. Catatan anekdot, yaitu sekumpulan catatan tentang sikap dan perilaku anak dalam situasi tertentu; 3. Percakapan, yaitu mendapatkan informasi tentang pengetahuan atau penalaran anak melalui bercakap-cakap; 4. Penugasan, yaitu pemberian tugas yang harus dikerjakan anak yang memerlukan waktu tertentu dalam pengerjaannya; 5. Unjuk kerja, yaitu asesmen yang menuntut anak didik untuk melakukan tugas dalm perbuatan yang dapat diamati; 6 . Hasil karya, yaitu hasil kerja anak didik setelah melakukan suatu kegiatan dapat berupa pekerjaan tangan atau karya seni; 7. Skala capaian perkembangan harian anak (checklist), yaitu cheklist yang diturunkan dari RPPH yang memuat indikator capaian perkembangan anak yang sudah ditetapakan sebelumnya, dan 8. Portofolio, yaitu kumpulan atau rekam jejak berbagai hasil kegiatan anak secara berkesinambungan.

Berdasarkan penuturan guru, teknik asesmen yang diterapkan di TK Khadijah AlMuayyada Sampang adalah observasi atau pengamatan, skala capaian perkembangan harian anak (checklist), dan hasil karya. Penerapan teknik observasi (pengamatan) biasanya guru melakukan pengamatan disaat proses kegiatan pembelajaran seperti ketika anak menyusun balok, menyebutkan angka dari 1-10, mampu menalar/menghubungkan kegiatan belajar dengan kehidupan dirinya, dan sebagainya. Untuk teknik checklist, guru menyesuaikan dengan indikator yang sudah ditetapkan di RPPH. Misal salah indikator berhungan dengan kognitif anak yaitu mampu mencocokkan gambar hewan dengan jenis makanannya (gambar di bawah), jika anak mampu menyelesaikan dengan benar atau ada kekeliruan guru menilai dengan menetapkan kriteria tertentu, misal BB (belum berkembang), MB (Masih berkembang), BSH (berkembang sesuai harapan), BSB (berkembang sangat baik), atau kriteria penilain lain seperti 3 bintang, 2 bintang, dan sebagainya.

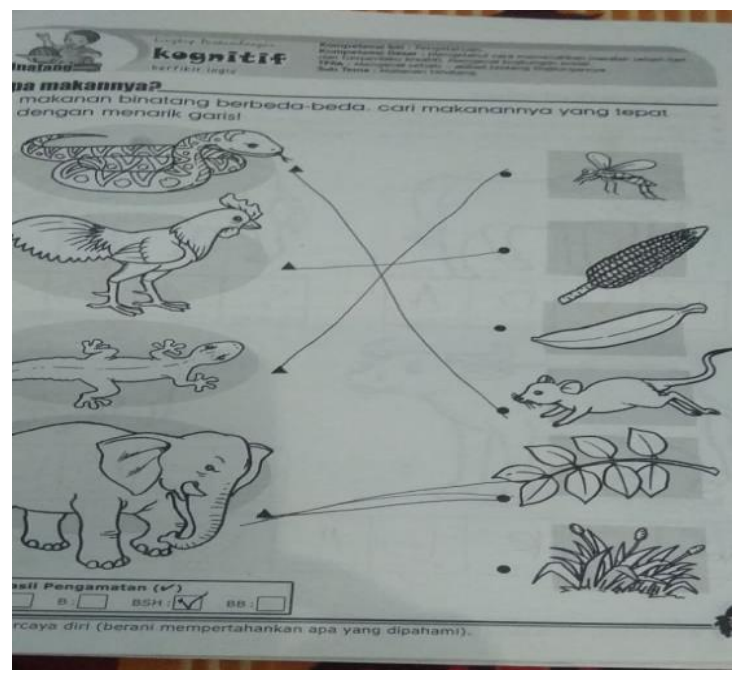

Gambar 1. Contoh checklist 
Penerapan teknik penilaian hasil karya tidak hanya digunakan dalam menilai aspek perkembangan seni anak, akan tetapi perkembangan kognitif juga bisa kita nilai. Menurut guru di TK tersebut kita bisa menilai sejauh mana ide dan imajinasi anak berkembang dan bagaimana mereka meyelesaikan kegiatan tersebut dengan tepat. Misalkan anak membuat pola/bentuk baju dari kardus kemudian dibagian pinggir diberi lubang untuk tempay memasukkan pita (menjahit), disini anak sudah mengenal tentang bentuk dari baju dan mampu memasukkan pita dengan pengulangan yang tepat dalam rangka mengembangkan kognitif sekaligus mengembangkan seni pada anak.

Pada hasil karya anak dapat dipajangkan dalam bentuk mandiri atau dibuat pameran karya anak yang disajikan secara bersama. Biasanya penilaian pada hasil karya hanya berupa komentar guru tentang karya yang sudah dibuat oleh anak, seperti 'sudah bagus', 'masih kurang, dilengkapi lagi ya', 'kurang bagus', 'kurang rapi',

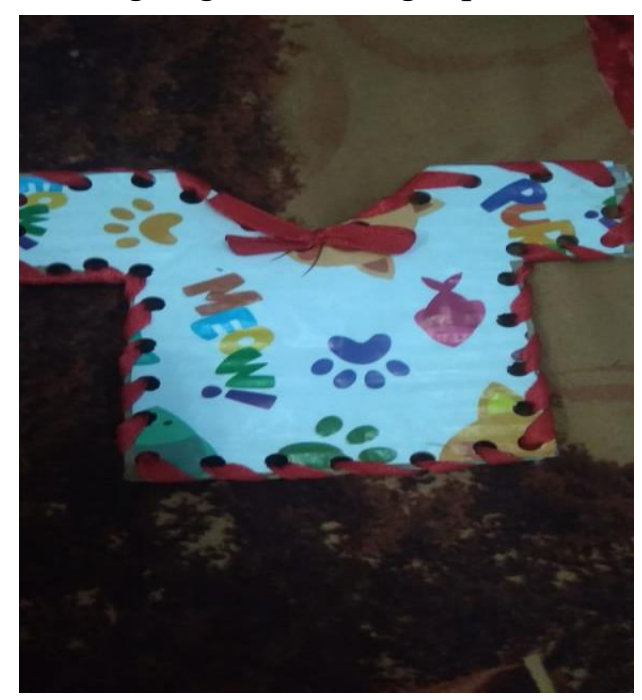

\section{Gambar 2. Contoh hasil karya anak}

Penilaian yang dilakukan di TK Khadijah Al-Muayyada Sampang dilakukan setiap hari, dengan cara mendokumentasikan baik berupa foto beberapa kegiatan yang dilakukan oleh anak dan lembar penilaian yang kemudian pelaporan perkembangan anak akan disusun dan dilaporkan oleh guru kepada orang tua setiap semester (Farhah: Wawancara). Hal inisejalan dengan prinsip asesmen yaitu berbagi dengan keluarga, yakni berbagi dan berkomunikasi dengan keluarga tentang perilaku dan perkembangan anak harus dengan persetujuan pihak yang berkait misalnya guru dan anak yang diamati (tergantung usia anak). dalam hal ini, seorang profesional perlu me adalah observasi atau pengamatan, skala capaian perkembangan harian anak (checklist), dan hasil karya.minta izin untuk menceritakan tentang anak pada orang tuanya.

Dengan adanya asesmen perkembangan kognitif di TK Khadijah Al-Muayyada Sampang memberikan dampak yang positif, baik untuk guru, anak didik, dan juga orang tua. Menurut guru di TK tersebut, dengan mengasesmen perkembangan kognitif anak, kita bisa tahu bahwa setiap anak memiliki kecepatan perkembangan kognitif yang berbeda, mengetahui materi kegiatan apa yang dirasa belum pas atau kurang tepat dan materi yang belum dicapai oleh anak sehingga guru bisa memperbaiki metode dan strategi yang digunakan. Dan jika ada permasalahan individual tentang anak yang lambat dalammateri tertentu, biasanya guru di TK tersebut memberikan bimbingan dengan telaten sampai anak tersebut benar-benar bisa dan mampu memahami konsep kegiatan tersebut.

Untuk anak didik, asesmen memberikan dampak positif karena guru bisa memberikan bimbingan dan solusi yang tepat dari hasil asesmen perkembangan kognitif 
yang kemudian dikomunikasikan kepada orang tua, sehingga orang tuapun bisa berkolaborasi dengan guru dalam memberikan stimulus sehingga mampu mengembangkan kognitif, baik di sekolah maupun di rumah.

Hal ini sejalan dengan tujuan dari kegiatan asesmen pada anak usia dini menurut Yus (2011: 40) dengan asesmen kita bisa memperoleh informasi yang berkaitan dengan pembelajaran seperti sejauh mana ketercapaian tujuan pembelajaran, sehingga kita mengetahui mana anak-anak yang berhasil, dan mana yang belum dalam aspek-aspek perkembangan yang telah dicapai dan yang belum dicapai, serta ditetapkan apakah pembelajaran dilanjutkan atau diulang.

\section{KESIMPULAN}

Materi kegiatan dalam mengembangkan kognitif anak di TK Khadijah Al-Muayyada Sampang berupa pengenalan konsep bilangan, mengenal, mengelompokkan, menghubungkan dan mengurutkan benda berdasarkan ukuran, warna, bentuk, fungsi, dan ciri-ciri lainnya. Teknik penilaian yang diterapkan di TK tersebut adalah observasi atau pengamatan, skala capaian perkembangan harian anak (checklist), dan hasil karya. Semua teknik penilaian tersebut digunakan untuk menilai perkembangan anak secara individu yang nantinya akan dilaporkan kepada orang tua setiap semesternya. Asesmen (penilaian) perkembangan kognitif di TK tersebut memiliki dampak positif yaitu guru mampu mengetahaui sejauh mana perkembangan anak, solusi apa yang akan diberikan ketika ada keterlambatan perkembangan kognitif, dan orang tua juga bisa mengetahui bagaiman perkembangan kognitif anak di sekolah dan stimulus apa yang bisa diberikan di rumah sehingga mendukung perkembangan kognitif anak.

\section{DAFTAR PUSTAKA}

Agustin, M,. \& Wahyudin, U. (2011). Penilaian Perkembangan Anak Usia . Bandung: Refika Aditama.

Ernawita. (2018). Assesmen Pembelajaran Pendidikan Anak Usia Dini dalam Kurikulum 2013. Academia Edu.

Fadlillah, M. (2017). Bermain \& Permainan Anak Usia Dini. Jakarta: Kencana.

Nugraha, Ali dkk. (2005). Kurikulum dan Bahan Belajara TK. Jakarta: Universitas Terbuka

Peraturan Menteri Pendidikan dan Kebudayaan Nomor 146 Tahun 2014 Tentang Kurikulum 2013 Pendidikan Anak Usia Dini.

Suyadi. (2016). Perrencanaan dan asesmen Perkembangan pada Anak Usia Dini (Studi Kasus pada Lembaga PAUD di Daerah Istimewa Yogyakarta). Golden Age: Jurnal Ilmiah Tumbuh Kembang Anak Usia Dini, 1(1), 65-83.

Suyanto, Slamet. (2005). Konsep dasar Pendidikan Anak Usia Dini. Jakarta: Dirjen Dikti Depdiknas.

Syah, Muhaibin. (2010). Psikologi Pendidikan Dengan Pendekatan Baru. Bandung: Remaja Rosdakarya.

Yus, Anita. (2011). Penilaian Perkembangan Belajar Anak Taman Kanak-Kanak. Jakarta: Pernada Media Group. 